\title{
An Evaluation of Comparative Study of Serum Ferritin Levels in Myocardial Infraction Cases
}

\author{
Sadhana Verma ${ }^{1}$, Prabha Verma ${ }^{2}$, Sapna Jaiswal ${ }^{3}$, Bhupinder Kaur Anand ${ }^{4}$, MPS Marwaha $^{5}$ \\ ${ }^{1}$ Professor, Department Of Biochemistry, LPS Institute Of Cardiology, GSVM Medical College ,Kanpur, ${ }^{2}$ Professor ,Department Of Biochemistry, M.L.B. Medical \\ College , Jhansi, ${ }^{3}$ Tutor, Department Of Biochemistry, Dr. Ram Manohar Lohia Institute Of Medical Sciences, Lucknow, ${ }^{4}$ Professor, Department Of Community \\ Medicine, SGT Medical College, Gurugram, ${ }^{5}$ Classified Specialist Aviation Medicine, Air Force Centre Medical Establishment, New Delhi.
}

\section{Abstract}

Background: MIs occur mostly due to coronary artery disease. The major risk factors of MIs are high blood pressure, smoking, diabetes, lack of exercise, obesity, high blood cholesterol, poor diet and excessive alcohol intake. MI usually involves the complete blockage of a coronary artery. Subjects and Methods: This study conducted in the department of cardiology \& biochemistry in LPS institute of cardiology, GSVM medical college ,Kanpur.. The population of this case - control study was 50 for each group. The duration of study was over a period of one year. Results: We were found that $42 \%$ patients were belongs to $41-50$ age group in case group, whereas in control group $52 \%$ followed by other age group. In this study we showed association of acute myocardial infraction with high serum ferritin. Conclusion: To reduce cardiovascular morbidity and mortality it is essential to monitor serum ferritin levels regularly.

Keywords: Myocardial infarction (MI), Electrocardiograms, Serum ferritin, Angiography

Corresponding Author: Dr. Prabha Verma, Professor, Department Of Biochemistry, M.L.B. Medical College , Jhansi.

Received: February 2019

Accepted: February 2019

\section{Introduction}

It has been estimated by World Health Organization (2004) that $12.2 \%$ of deaths were due to ischemic heart disease which is leading cause of death in myocardial infarction (MI). MIs occurs mostly due to coronary artery disease. ${ }^{[1]}$ The major risk factors of MIs are high blood pressure, smoking, diabetes, lack of exercise, obesity, high blood cholesterol, ${ }^{[2,3]}$ poor diet and excessive alcohol intake. MI usually involves the complete blockage of a coronary artery. ${ }^{[4]}$ It is caused by a rupture of an atherosclerotic plaque. The less common cause of MIs are coronary artery spasms. It may be due to cocaine, significant emotional stress and extreme cold. ${ }^{[5,6]}$ There are number of tests which are beneficial with diagnosis of MIS. It includes electrocardiograms (ECGs), blood tests and coronary angiography. ${ }^{[7]}$ If ST elevation is present then an ECG may confirm it. ${ }^{[8]}$ The most commonly used blood tests are troponin and 7creatinine kinase $\mathrm{Mb} .{ }^{[9]}$ According to $\mathrm{WHO}$ criteriato diagnose MI are clinical history of ischemic type, chest pain lasting for more than 20 minutes, changes in serial ECG tracings, rise and fall of serum cardiac biomarkers. Ferritin is abundant intracellular protein that stores iron and release it in controlled manner. The protein is produced by almost all living organism. It includes algae, bacteria, higher plants and animals. It acts as a buffer against iron deficiency and iron overloading in humans. In most tissues, ferritin is found as a cytosolic protein, but a very little amount is secreted into the serum where it functions as an iron carrier ${ }^{[10]}$. It stores iron in non-toxic form, deposits in safe form and transports to areas where it is required. Free iron is toxic to cells. ${ }^{[1]}$ As itacts as a catalyst in the formation of free radicles from reactive oxygen species via the Fenton reaction. Vertebrates evolve an elaborate set of protective mechanism to bindiron in various tissue compartments. Iron is stored in a protein complex as ferritin or hemosiderin within cells. Free iron has been related with ischemic myocardial damage and lipid peroxidation (LP). It has been hypotheses as to how free iron may accelerate the progression of atherosclerosis or contribute to myocardial injury after ischemic event in several researches. National Health and Nutrition Examination Survey (1988-1994) reported a significant positive correlation in iron storage and heart disease risk. There are very few studies available in theliterature. Therefore, the present study was done to find out the relation of serum ferritin with myocardial infarction.

\section{Subjects and Methods}

Study area: This study conducted in the department of cardiology \& biochemistry in LPS institute of cardiology, GSVM medical college, Kanpur.

Study Population: The population of this case - control study was 50 for each group.

Study duration: The duration of study was over a period of one year.

Data collection: All subjects were subjected to detailed 
history, physical examination and relevant investigations. Study subjects were evaluated for serum creatine kinaseMB fraction (CK-MB), Trop-T, serum ferritin along with complete blood counts etc. All patients were interviewed as per the prepared proforma and then complete clinical examination and laboratory investigations were done.

Data Analysis: Data were analyzed by using Microsoft excel.

\section{Results}

In this study, we were including 50 patients as cases and 50 as a control. Out of 50 cases we had $70 \%$ male and $30 \%$ female in cases, while in control $72 \%$ male \& $28 \%$ female. We were found that $42 \%$ patients were belongs to $41-50$ age group in case group, whereas in control group 52\% followed by other age group. In this study we showed association of acute myocardial infraction with high serum ferritin [Table 5].

Table 1: Distribution according to gender

\begin{tabular}{|l|l|l|l|l|}
\hline Gender & Cases & \% & Control & \% \\
\hline Male & 35 & $70 \%$ & 36 & $72 \%$ \\
\hline Female & 15 & $30 \%$ & 14 & $28 \%$ \\
\hline Total & 50 & $100 \%$ & 50 & $100 \%$ \\
\hline
\end{tabular}

Table 2: Distribution according to age

\begin{tabular}{|l|l|l|l|l|}
\hline Age & Cases & $\%$ & Contrl & $\%$ \\
\hline $21-30$ & 5 & $10 \%$ & 1 & $2 \%$ \\
\hline $31-40$ & 6 & $12 \%$ & 8 & $16 \%$ \\
\hline $41-50$ & 21 & $42 \%$ & 26 & $52 \%$ \\
\hline $51-60$ & 7 & $14 \%$ & 11 & $22 \%$ \\
\hline$>60$ & 11 & $22 \%$ & 4 & $8 \%$ \\
\hline Total & 50 & $100 \%$ & 50 & $100 \%$ \\
\hline
\end{tabular}

Table 3: Distribution according to comorbidities

\begin{tabular}{|l|l|l|l|l|}
\hline Comorbidities & Cases & $\%$ & Control & $\%$ \\
\hline Hypertension & 16 & $32 \%$ & 14 & $28 \%$ \\
\hline DM & 13 & $26 \%$ & 11 & $22 \%$ \\
\hline
\end{tabular}

\section{Table 4: Association of acute myocardial infraction with high} serum ferritin

\begin{tabular}{|l|l|l|l|l|}
\hline Serum Ferretin Level & Cases & \% & Control & \% \\
\hline$<100$ & 5 & $10 \%$ & 17 & $34 \%$ \\
\hline $100-199$ & 10 & $20 \%$ & 13 & $26 \%$ \\
\hline $200-299$ & 7 & $14 \%$ & 11 & $22 \%$ \\
\hline$>300$ & 28 & $56 \%$ & 9 & $18 \%$ \\
\hline Total & 50 & $100 \%$ & 50 & $100 \%$ \\
\hline
\end{tabular}

\section{Discussion}

The present study consisted of 100 patients (50 cases and 50 controls) toevaluate the levels of serum ferritin in acute myocardial infarction. Globally, the incidence of acute myocardial infarction is increasing among all age groups andin both sexes. In AMI, due to sustained ischemia, irreversible tissue injury occurs. Recent studies have revealed that the innate immune system is activated sequentially and mediating both injury and repair mechanisms. ${ }^{[12,13]}$ The role of ferritin in pathogenesis of coronary artery disease (CAD) has generated considerable interest now a days. A positive relationship between body iron stores and coronary artery diseases have been found in epidemiological studies. ${ }^{[14,15]}$ Afterward, evidence of an association of elevated serum ferritin and increased risk of AMI were observed by various authors. ${ }^{[16,17]}$. These findings are similar to our findings. Though findings other studies did not show significant correlation between high ferritin and risk of AMI. ${ }^{[18,19]}$ It could be possible that overloading of iron leads to increased lipid peroxidation and foam cell formation. But apart from this the chemical properties of oxidized lipoproteins were found to be chemotactic to blood monocytes, facilitate the entry of lipoproteins by a cytotoxic endothelial injury, and give rise to smooth muscle cell proliferation ${ }^{[20,21 \& 22]}$.In contrasts native low density lipoprotein lacks all these atherogenic potentials. 20,22A study showed a strong relation between sonographically assessed carotid atherosclerosis and prominent iron stores in both sexesmainly when associated with hypercholesterolemia. ${ }^{[23]}$ Therefore, lipid peroxidation may establish an initiating and crucial step in the development of fatty streaks and plaques. Blood donation has also been reported to be linked with decreased risk of cardiovascular events. ${ }^{[24]}$

In this study, mostly patients belonged to 41-50 years in both the groups. Mostly patients, in both the groups were males and the difference was statistically notsignificant as per Chi-square test $(p>0.05)$. In a study by Vijaya BM et al, 25 found the mean age were $45.7 \pm 3.8,46.4 \pm 4.1$ and $46.2 \pm 4.5$ in control group and group I and II respectively. The averagenumber of Male and female were 82/19.

In our study, hypertension and diabetes mellitus were more common in Cases Group as compared toControl Group ( $32 \%$ vs. $26 \%$ and $28 \%$ vs. $22 \%$ respectively).Moradi M et al, 26 conducted a study which consisted of 50 consecutive patients with first acute myocardialinfarction (AMI), and a control group $(\mathrm{n}=50)$ without history of AMI. The study found no significantdifference in risk factors including diabetes mellitus, hypertension between thegroups.

\section{Conclusion}

This study concludes that, For AMI, higher levels of ferritin, seems to be a strong risk factor. Along with other risk factor, higher ferritin level can easily be identified during routine hematological analysis. To reduce cardiovascular morbidity and mortality it is essential to monitor serum ferritin levels regularly.

\section{References}

1. Lee IM, Shiroma EJ, Lobelo F, Puska P, Blair SN, Katzmarzyk PT. Effect of physical inactivity on major non-communicable diseases worldwide: an analysis of burden of disease and life expectancy. 婮e Lancet. 2012;380 (9838): 219-29.

2. Mehta PK, Wei J, Wenger NK. Ischemic heart disease in women: A focus on risk factors. Trends in Cardiovascular Medicine. 2015;25(2):140-151. 
3. Mendis S, Puska P, Norrving B. Global atlas on cardiovascular disease prevention andcontrol (PDF) 1stEd. Geneva. World Health Organization in collaboration with the World Heart Federation and the World Stroke Organization. WHO. 2011. pp. 3-18.

4. What is a heart attack? https://www.nhlbi.nih.gov/health/healthtopics/topics/heartattack/ causes. December 17, 2013. Retrieved 24 February 2015

5. What Causes a Heart Attack?.https://www.nhlbi.nih.gov/health/healthtopics/topics/ heart attack. December 17, 2013. Retrieved 24 February 2015.

6. Devlin, RJ, Henry JA. Clinical review: Major consequences of illicit drug consumption. Critical Care. 2008;12 (1): 202

7. "How Is a Heart Attack Diagnosed?". https://www.nhlbi.nih.gov/health/healthtopics/topics/ heart attack. December 17, 2013. Retrieved 24 February 2015.

8. Steg PG, James SK, Atar D, Badano LP, Blömstrom-Lundqvist C, Borger MA et al. Task Force on the management of ST-segment elevation acute myocardial infarction of the European Society of Cardiology, (ESC). Eur Heart J. 2012;33(20):2569-619.

9. 'Nomenclature and criteria for diagnosis of ischemic heart disease'.Report of the Joint International Society and Federation of Cardiology/World Health Organization task force on standardization of clinical nomenclature.Circulation. 1979;59 (3): 607-9.

10. Steptoe A, Kivimäki M. Stress and cardiovascular disease.Nature Reviews Cardiology.2012;9 (6): 360-70.

11. Torti FM, Torti SV. Regulation of ferritin genes and protein.Blood. 2002;99 (10): 3505-16.

12. Nahrendorf M, Pittet MJ, Swirski FK. Monocytes: protagonists of infarct inflammation and repair after myocardial infarction. Circulation. 2010;121:2437-45.

13. Hilgendorf I, Gerhardt LM, Tan TC et al. Ly-6C high monocytes depend on $\mathrm{Nr} 4 \mathrm{a} 1$ to balance both inflammatory and reparative phases in the infarcted myocardium. CircRes.2014;114(10):1611-22.

14. Salonen JT, Nyyssönen K, Korpela H et al. High stored iron levels are associated with excess risk of myocardial infarction in eastern Finnish men. Circulation 1992;86:803-11.

15. Solymoss BC, Marcil M, Gilfix BM. The place of ferritin among risk factors associated with coronary artery disease. Coron Artery Dis 1994; 5:231-5.

16. Salonen JT, Nyyssönen K, Salonen R. Body iron stores and the risk of coronary heart disease. N Engl J Med 1994;331:1159.

17. Delphine W, Silvia CR, Biswas S et al. Ferritin - a potent threat for acute myocardial infarction. J Assoc Physicians (India) 2003; 51:94750.

18. Reunanen A, Takkunen $\mathrm{H}$, Knekt $\mathrm{P}$ et al. Body iron stores, dietary iron intake and coronary heart disease mortality. J Intern Med 1995;238:223-30.

19. Gupta R, Rastogi S, Nagar R et al. Dietary and serum iron, body iron stores and coronary heart disease. J AssocPhysicians (India) 2000; 48:489-92.

20. Steinberg D, Parthasarathy S, Carew TE et al. Beyond cholesterol: modifications of low density lipoprotein that increase its atherogenicity. N Engl J Med. 1989; 320:915-924.

21. Boulanger CM, Tanner FC, Bea ML et al. Oxidized low density lipoproteins induce mRNA expression and release of endothelin from human and porcine endothelium. Ore Res. 1992; 70:1191-1197.

22. Quinn MT, Parthasarathy S, Fong LG et al. Oxidativelymodified low density lipoproteins: a potential role in recruitment and retention of monocyte/ macrophages during atherogenesis. ProcNatlAcadSci USA. 1987; 84:2995-2998

23. Kiechl S, Willeit J, Egger G et al. for the Bruneck Study Group. Body iron stores and the risk of carotid atherosclerosis.Prospective results from the Bruneck Study. Circulation 1997;96:3300-7.

24. Meyers DG, Strickland D, Maloley PA et al. Possible association of a reduction in cardiovascular events with blood donation. Heart 1997;78:188-93.

25. Vijaya BM, Srilekha S,Saranya M et al. Assessment of ferritin and its association with $\mathrm{C}$ - reactive protein and malondialdehyde in acute myocardial infarction. Int J Res Med Sci 2015;3:3581-5.

26. Moradi M, FarnazFariba, Ali SadeghiMohaseli. Relation between the Serum Ferritin Level and the Risk for Acute Myocardial Infarction.Journal of Research in Health Sciences.2015;15(3):147-151.

Copyright: () the author(s), 2019. It is an open-access article distributed under the terms of the Creative Commons Attribution License (CC BY 4.0), which permits authors to retain ownership of the copyright for their content, and allow anyone to download, reuse, reprint, modify, distribute and/or copy the content as long as the original authors and source are cited.

How to cite this article: Verma S, Verma P, Jaiswal S, Kuar B, Marwaha MPS. An Evaluation of Comparative Study of Serum Ferritin Levels in Myocardial Infraction Cases. Asian J. Med. Res. 2019;8(1):BC14-BC16.

DOI: dx.doi.org/10.21276/ajmr.2019.8.1.BC5 